\title{
Tourism Impact on Conservation and Utilization of Borobudur Temple After Being Declared as Ten New Bali Tourist Destination in Indonesia
}

\author{
Cerry Surya Pradana ${ }^{1}$, Carlos Iban $^{2}$, R. Setyastama ${ }^{3}$ \\ ${ }^{1}$ Departement of Language, Art, and Culture Management, Faculty of Vocational College, Universitas Gadjah Mada, \\ Indonesia \\ ${ }^{2}$ Departement of Language, Art, and Culture Management, Faculty of Vocational College, Universitas Gadjah Mada, \\ Indonesia \\ ${ }^{3}$ Yayasan Irama Tjitra Yogyakarta, Indonesia
}

\begin{abstract}
Borobudur as a world heritage site is one of $10 \mathrm{New}$ Bali Tourist Destination or 10 Priority Tourist Destination in Indonesia. The problem arises as government's aim to attract tourists as many as possible can be contrary to the conservation principles. This study aimed to identify the impact of the establishment of Borobudur Temple as one of 10 priority tourist destinations, specifically in terms of conservation and utilization. In addition, it is aimed to view the readiness and strategy of the manager of Borobudur Temple Heritage Site toward the policy of 10 New Bali Tourist Destination. The method used in this study is descriptive qualitative. Data will be collected by doing observation and indepth interview as well as literature review. The data are analysed using the hermeneutic paradigm in which researchers expect the interpretations of the manager of Borobudur Temple Heritage Site dealing with the topic of the study. Data analysis is done by using hermeneutic paradigm which is expected to answer the research questions. The preliminary findings of this study, that are based on interview and literature review, state that there is a different job description between BKB and PT. TWCBRB. This study has found out the impact of the establishment of Borobudur Temple as 10 New Bali Tourist Destination in conservation and utilization term.
\end{abstract}

Keywords: Borobudur Temple, heritage tourism, tourism impacts, 10 New Bali, 10 priority tourist destination.

\section{INTRODUCTION}

The development of priority tourism destinations made by the Ministry of Tourism (Kemenpar) of the Republic of Indonesia, consists of ten destinations that are expected to become 10 New Bali destinations [1]. However, in 2017, the Indonesian Minister of Tourism, Arief Yahya, stated that only four destinations would be reallocated to become priority tourism destinations, namely Borobudur Temple, Lake Toba, Mandalika, and Labuan Bajo [2]. In 2019, the level of tourist arrivals (foreign tourists) to the Borobudur Temple is targeted at 2 million people [3]. It is inversely proportional to the statement of Borobudur Conservation Center (BKB) staff, who said that maximum carrying capacity in Borobudur Temple is 123 people to climb(stepping on rocks) the temple at one time, 528 people in the temple yard, and 10,308 people in the temple yard [4].

In 2017, the average number of domestic tourists visiting Borobudur Temple every day is at 7,000 people, while foreign tourists are $700-800$

\footnotetext{
* Correspondence address:

Cerry Surya Pradana

E-mail : cerrysuper@ugm.ac.id

Address : Universitas Gadjah Mada, Bulaksumur,

Kabupaten Sleman, Daerah Istimewa Yogyakarta 55281
}

per day (Tempo.co/ANTARA, 11 August 2017). The Government of Indonesia in 2019 targets the increasing number of tourist arrivals from 750,000 people per year to 2 million people per year (Republika.co.id, 10 February 2018). This target is said from foreign tourists alone. Thus, there is a possibility that domestic tourists visiting Borobudur Temple will be even greater than in previous years. The number of visitors certainly have the potential to damage the temple rocks trampled by footwear used by tourists (Nainggolan, pekanbaru.tribunnews.com, October 14, 2015). Another concrete example that often occurs at site locations is the frequent tourists taking selfies, which do not heed the rules for the sake of getting photos that are considered satisfactory. Cases like this occur in several locations, including the Borobudur Temple, where tourists often climb the stupa for the sake of existence (Oda, Tribunnews.com, 2017). In addition, it is not uncommonly sight for the author to find tourists and visitors at temples and cultural heritage sites, who do not heed the rules, such as smoking clandestinely in the site and ascending to a place that has been marked No Prohibited Up/Prohibited Sitting.

The problem of tourism in Indonesia not only caused by tourists. It is supported by the conclusion that there is a conflict of interest in 
Indonesian society regarding the management of cultural heritage $[5,6]$. Thus, the problem of tourism in Indonesia must be viewed from various perspectives. The entry of Borobudur Temple in the Borobudur, Prambanan, and Ratu Boko Tourism Park Limited Companies (PT. TWCBPRB), relates to the existence of the Borobudur Conservation Center (BKB). If PT. TWCBPRB focuses on marketing and increasing tourist visits, so it is different from BKB, which has a focus on conservation and preservation.

This conservation activity is inversely proportional to the job of PT. TWCBPRB, which are the manager of tourism activities at Borobudur Temple and aim to bring as many tourists as possible. Not to mention currently, the Republic of Indonesia's Ministry of Tourism has formed the Borobudur Authority Agency (BOB), which has also contributed to the increasing numbers of agencies involved in the planning and management of the Borobudur Temple Area.

The Government of Indonesia, through the Ministry of State-Owned Business Agency (BUMN), is making a solution so that visitors at Borobudur Temple can provide benefits to residents around the temple. The solution is to create a Village Economic Center (Balkondes), which is supported by 18 SOBAs (BUMN). Until now, there have been 20 Balkondes around the Borobudur Temple. The efforts made by the Indonesian government, in this case, the Ministry of Tourism, should be appreciated. However, it is also important to consider the problem of carrying capacity of a tourist destination that will or is being developed. Thus, tourism activities can work while also give some attention to the principle of conservation.

Research on the impact of tourism in Borobudur Temple was conducted in a previous study, which stated that tourism activities in Borobudur Temple were not controlled because of the large number of visitors, can be anticipated by adding supervision and application of the rules [7]. Wahyuningsih from BKB, studied the Borobudur Cultural Heritage Conservation stated that there needs to be a pattern of visiting arrangements at Borobudur Temple [8].

Biantoro and Ma'arif [9] wrote that the communities around Borobudur Temple, who do not work in Borobudur Temple, do not feel the benefits of the Borobudur Temple economically. This research, however, is becoming less relevant, because nowadays there are already 20 Village Economic Center (Balkondes) prepared to absorb the potential economical income from visitors who come to the Borobudur area. Another research found that there were negative and positive impacts on the community around the Borobudur Temple. In terms of economics and education, there is a good increase. While in terms of security, there is actually a decline, in addition to the increasingly crowded population around Borobudur Temple [10].

Cultural impacts in tourism occur because there are factors that result in so. Pitana [11] mentioned 13 factors that cause socio-cultural impacts in tourism, namely (1) Comparison of tourist numbers to local residents; (2) The dominant object that becomes the tourism attraction and the needs of tourists related to it; (3) The forms of attraction presented (nature, culture and other forms); (4) Tourism structure and organization in tourism destination area; (5) Differences in economic and cultural between tourists and local people; (6) Difference between tourist culture and local people; (7) Level of autonomy from tourism destination area; (8) Speed of tourism growth; (9) The level of tourism development (still in its early days or when saturation has started); (10) The level of DTW economic development; (11) The social structure of the local community; (12) Types of resorts developed; and (13) The role of tourism in the tourism destination area economy.

Ahimsa-Putra and Raharjana [12] explained that the cultural impact meant the various changes that occur in the value system, rules, and various rules as a result of changes in the physical, social, and cultural environment of the system. Cultural impacts are divided into two parts, namely based on the nature or character of the impact and based on its aspects. Based on the nature or character, cultural impacts are divided into positive impacts and negative impacts. Based on its aspects, it is divided into qualitative and quantitative impacts.

Yoeti [13] stated that tourism often has a negative impact on socio-cultural activities, while the positive effects are often in economic terms. Tourism as a cultural impact gives rise to what is called by Yoeti with the commercialization of art. One example is the Kecak Dance performance in Bali. The dance, which is a fragment of the Ramayana, is a compact and concise version of the show, even though the actual performance can take two to three nights. In addition, there was a falsification of handicrafts (imitation), demonstration effects, the demoralization of 
young people, and the commercialization of customs.

Ardika [14] stated that heritage tourism is an alternative tourism that is useful for reducing mass tourism activities which have a more capitalist tendency in developing the tourism industry. Heritage tourism, currently has a rapid development, due to the tendency for tourists to look for new and authentic things.

Park [15] also stated that heritage tourism is a dominant tourism activity looking at material and non-material cultural forms originating from the past. The most important thing that was conveyed by Park was that in the context of tourism, the heritage that was intended was neither static nor permanent. The context of this heritage is constantly evolving and reinterpreted, in an effort to attract tourists and reflect sociocultural changes in the contemporary world. Park also said the relationship between heritage and tourism is a complex, complicated, and symbiotic relationship.

The United Nations Educational, Scientific, and Cultural Organization (UNESCO) stated that heritage tourism is a tourism activity to enjoy a variety of local customs, cultural heritage objects, and nature. It is along with all its contents in its original place, which aims to provide knowledge and understanding of cultural and natural diversity for visitors [16]. It also mentioned in the article, that the involvement of local communities had an important role in determining the success of heritage tourism.

Research and writings on the theme of the impact of tourism, especially related to cultural heritage, have been written by researchers from academia and practitioners alike. However, research on the impacts of tourism-related after the decision on Borobudur Temple as one of the priority destinations has not been studied indepth, mainly relating to the management of destinations in terms of conservation and utilization. Therefore, this research aimed to determine the tourism impacts on the conservation and utilization of Borobudur Temple decided after being declared as Ten New Bali tourists destination in Indonesia, that has never been studied previously.

\section{RESEARCH METHOD}

The research method is a method used to solve problems in a case study. The method used in this research is a descriptive qualitative method. It is how to solve the problem under study, by describing the object of research in detail based on the facts contained in the field. The reasoning method used in completing this research is deductive. Analytical reasoning that moves from the study of general facts or symptoms, which then concluded to be specific phenomena [17]. The following are the steps that will be carried out in this research.

\section{Data Collection}

This stage carried out to obtain data related to research. Data collected at this stage consists of primary data and secondary data. Primary data searched in two ways, namely observation or direct observation and interviews, while secondary data obtained through documentation techniques.

\section{Literature Study/Documentation Techniques}

A literature study was conducted to obtain secondary data related to the research topic. Literature study aims to obtain information about responsible tourism and management of cultural heritage objects, in this case, Borobudur Temple. The study of responsible tourism can be obtained through various libraries or scientific publications, which are available in various places such as data libraries and other locations. Likewise, data on the management of cultural heritage objects as tourist attractions were also collected. This literature study aims to complete the data collected through observation and support the arguments to be conveyed.

\section{Observation}

The observation locations, which are the main focus, located in the core zone, where conservation activities carried out. Whereas supporting observation locations will be carried out in buffer zones, development zones, and support zones. The role and/or participation of managers, visitors, and government institutions in these zones were observed.

\section{Interview}

The interview stage conducted to complete the observation data and literature study. The data were related with the responsible tourism and its relationship with the building of cultural heritage, especially in Borobudur Temple. Indepth interviews were conducted with relevant informants. Parties taken as in-depth informants consisted of managers and related government institutions. The manager who will be the guest speaker is from PT. Taman Wisata Borobudur, Prambanan, and Ratu Boko (PT. TWCBPRB). It is because the PT is the party who is directly responsible for tourism activities in the 
Borobudur Temple. Researchers will interview two types of speakers, namely the leadership of PT. TWCBPRB and the person in charge of representing PT. TWCBPRB at Borobudur Temple.

The second party who became the resource person was the leader and officer of the Borobudur Conservation Center (BKB), which was the manager in charge of conservation, especially about the sustainability of the preservation of Borobudur Temple. This party cooperates and is closely related to PT. TWCBPRB in management at Borobudur Temple. The selection of BKB as a resource was due to its association with the management of tourism in Borobudur Temple. In contrast to PT. TWCBPRB, which is oriented towards tourism activities, Village Economic Center (Balkondes) is oriented towards conservation.

\section{RESULT AND DISCUSSION}

Based on literature studies and interviews, the division of work zones associated with the zoning of Borobudur Temple is obtained. Where the Borobudur Temple is divided into at least three zones, namely zone $I$ is the Conservation Zone, which is managed by the Borobudur Conservation Office; zone II is a buffer zone, which is managed by PT. Taman Wisata Borobudur, Prambanan, and Ratu Boko temples; and zone III is the Utilization Zone, which is managed by the Regional Government of Magelang Regency. These three zones become a benchmark in the implementation of tourism activities, as well as the division of responsibilities among managers involved in tourism activities at Borobudur Temple.

\section{Impacts on Conservation}

The zoning distribution conducted at the Borobudur Temple is a provision that has been made by the Government of the Republic of Indonesia. The party responsible for preservation in Borobudur Temple is BKB, which is under the Indonesian Ministry of Education and Culture. BKB made several policies related to preservation efforts carried out at Borobudur Temple.

First, the BKB made a study that produced the maximum number of visits (carrying capacity) in Zone I (the zone where the main temple located). The number of visits intended in one unit of time (for example, in 1 hour of visit), which is 128 visitors. For conservation, BKB also limits the number of visitors in Zone II to 523 visitors and Zone III to $\pm 10,000$ visitors at the same time. Thus, if the opening hours of the visit at Borobudur Temple, for example, are for 10 hours, then the maximum number of visitors entering zone I is 128 people multiplied by 10 hours, for a total of 1280 visitors.

Secondly, based on the data obtained, there are obstacles in the implementation of conservation in Borobudur Temple, which is carried out by BKB. These constraints are due in theory, Zone I is the responsibility of the BKB, which is a conservation Zone. However, in practice, tourists who come to Borobudur, enter Zone I, where these tourists are the responsibility of PT. TWCBPRB is responsible for Zone II. Thus it can be stated that PT. TWCBPRB as the person in charge of tourism puts tourists in Zone I, which is the domain of Zone I. So that the responsibilities of officers overlap, whether it is the responsibility of BKB or PT. TWCBPRB.

Third, based on interviews, the BKB does not really care about the large number of visitors who come to Borobudur Temple. They also did not question the Ministry of Tourism targeting any number of visits, to Borobudur. As long as the maximum number of visitors in each zone, according to what they have made before. In addition, they stated that Borobudur was not only composed of one temple but a cultural heritage area in Magelang Regency. Thus, the BKB hopes that there will be a fair visit to the Borobudur area.

\section{Impacts on Utilization}

PT. TWCBPRB, based on the division of work zones, is responsible for zone II in the Borobudur Temple Area. Zone II or buffer zone, as the name implies, is a buffer from Zone I (Conservation Zone). If related to tourism, zone II is a supporter of tourism activities carried out in zone I. In relation to the impact of tourism on the utilization of Borobudur Temple, there are several impacts that occur. The following is an impact that occurred as a result of the disconnection of Borobudur Temple as a new 10 Bali tourism destination, which later developed into a priority tourist destination.

First, the Ministry of Tourism's target of bringing in two million foreign tourists (tourists) in Borobudur, becomes the main focus that has a big impact in the region. Based on the 2018-2019 Strategic Plan Book made by the Ministry of Tourism [18], the target of foreign tourist arrivals in 2018 of $19 \%$ and $15 \%$ in 2019, is inversely proportional to the target of increasing tourist arrivals (wisnus) by $1.85 \%$ in 2018 and $1.85 \%$ in 2019. The increase in the number of tourist arrivals (both domestic and international) has an 
impact on the use that occurs in Borobudur Temple related to tourism.

Secondly, there is a target of the Indonesian government through the Ministry of Tourism relating to the amount of tourism investment entering the Borobudur Area, which is four hundred billion rupiah $(400,000,000,000.00$ IDR) in 2018 and five hundred billion rupiah $(500,000,000,000.00$ IDR) in 2019. Meanwhile, the number of tourist attractions in Borobudur targeted to increase by five attractions in 2018 and ten attractions in 2019. In addition, the number of tourism businesses is expected to increase to 224 businesses in 2018 and to 230 businesses in 2019.

Based on the area of responsibility, these targets are realization targets, which must also be met by PT. TWCBPRB, where they get the mandate to manage zone $\mathrm{II}$ in the Borobudur Temple area. In addition, this is in line with the main tasks and functions as a State-Owned Enterprise (BUMN), whose job is to seek and obtain as much financial income. However, although PT. TWCBPRB works in zone II, but tourists who enter Borobudur Temple are also allowed to enter zone I which is part of BKB.

\section{Discussion}

Based on the research results above, there are two things that can be discussed. First, the conservation that BKB wants is contrary to the target of tourist visits by PT. TWCBPRB. BKB does not make an issue with any number of tourists coming to the Borobudur area, as long as it follows the maximum number of visits in each zone at a time. Unlike the case with PT. TWCBPRB, who 'sells' Borobudur area with Borobudur Temple as the main attraction and has a minimum target of the visit.

Second, until now, the author still could not understand whether what PT really wanted. TWCBPRB is the number of tourists or the quantity of money received. If the targeted quantity is tourists, it will always conflict with the conservation efforts carried out by BKB. However, if what is desired is the quantity of cash income, then the target can be achieved, both the target of cash income and conservation.

\section{CONCLUSION}

The impact of tourism on conservation and utilization in the Borobudur Temple after being determined as a priority tourist destination occurs in several aspects. From a conservation standpoint, conservation work is getting tougher with this policy. It is due to the limited supervision team, while the number of tourists targeted to come is always increasing. In essence, the BKB as a preserver of conservation in the Borobudur Temple Area has no objection to the increase in tourist targets, as long as it adjusts to the capacity of the visits they have made. When viewed from the aspect of utilization, the PT. TWCBPRB as a BUMN strives to meet the targets set by the government, in this case, the Ministry of Tourism of the Republic of Indonesia.

The relationship between conservation and utilization of the Borobudur Temple Area needs further attention. Thus, research on this matter needs to be done, with the hope of finding the right formula in applying the principles of conservation and utilization in the area side by side. In addition, it is also necessary to ascertain the desires of the Government of Indonesia in this case the Ministry of Tourism (current nomenclature of the Ministry of Tourism and Creative Economy), regarding what is meant in quantity, whether the quantity of visitors or the quantity of income obtained as foreign exchange.

\section{REFERENCES}

[1] Ratman, D. R. 2016. Pembangunan destinasi pariwisata prioritas. Akselerasi pembangunan kepariwisataan dalam angka pencapaian target 12 juta wisman dan 260 juta wisnus 2016. National Coordinating Meeting. Indonesian Ministry of Tourism. Jakarta.

[2] Gumelar, G. 2017. 10 Bali baru kini tinggal empat lokasi. Available at: https://www.cnnindonesia.com/gayahidup/20171116201131-269-256186/10bali-baru-kini-tinggal-empat-lokasi.

[3] Raharjo, B. 2018. 2019, wisatawan ke Borobudur ditarget 2 juta orang. Available at: https://www.republika.co.id/berita/eko nomi/korporasi/18/02/10/p3xe2m4152019-wisatawan-ke-borobudur-ditarget-2juta-orang.

[4] Fitriana, I. 2017. Cegah kerusakan, sebetulnya berapa kapasitas pengunjung Candi Borobudur? Available at: https://travel.kompas.com/read/2017/07/1 1/140500427/cegah.kerusakan.sebetulnya. berapa.kapasitas.pengunjung.candi.borobu dur.

[5] Nuryanti, W. 2009. The role of heritage tourism in communityplanning and development. Gadjah Mada University Press. Yogyakarta.

[6] Tanudirdjo, D. A. 2003. Warisan budaya untuk semua: arah kebijakan pengelola 
warisan budaya Indonesia di masa mendatang. Paper presented at the $5^{\text {th }}$ Cultural Congress in Bukittinggi. 19-23.

[7] Taufik, M., and S. Atmosudiro. 2005. Minimalisasi dampak negatif Candi Borobudur sebagai objek wisata. Jurnal Humanika 18(3), 425-437.

[8] Wahyuningsih, I. 2010. Physical carrying capacity (daya dukung fisik) Candi Borobudur. Jurnal Konservasi Cagar Budaya 4(1), 30-35.

[9] Biantoro, Rudi dan Ma'arif, Samsul. 2014. "Pengaruh Pariwisata Terhadap Karakteristik Sosial Ekonomi Masyarakat Pada Kawasan Objek Wisata Candi Borobudur Kabupaten Magelang", dalam Jurnal Teknik PWK. Volume 3, no.4, hlm. 1038-1047.

[10] Hamzah, F., H. Hary, and Wigati. 2018. Evaluasi dampak pariwisata terhadap sosial ekonomi masyarakat lokal. Jurnal Pariwisata 5(3), 195-202.

[11] Pitana, I G. 1999. Pelangi pariwisata Bali. Bali Post Publisher. Denpasar.

[12] Ahimsa-Putra, H. S., and D. T. Raharjana. 2001. Dampak sosial budaya pembangunan pariwisata. Jurnal Nasional Pariwisata 1(1), 5-9.

[13] Yoeti, O. A. 2008. Perencanaan dan pengembangan pariwisata, $2^{\text {nd }}$ Ed. PT Pradnya Paramita. Jakarta:

[14] Ardika, I W. 2015. Warisan budaya perspektif masa kini. Udayana University Press. Denpasar.

[15] Park, H. Y. 2014. Heritage tourism. Routledge. London.

[16] Cahyadi, R., and J. Gunawijaya. 2009. Pariwisata pusaka: masa depan bagi kita, alam, dan warisan budaya bersama. UNESCO Office. Jakarta.

[17] Nawawi, H. 2003. Metode penelitian bidang sosial. Gadjah Mada University Press. Yogyakarta.

[18] Republic of Indonesia Ministry of Tourism. 2018. Rencana Strategis 2018-2019. Ministry of Tourism. Jakarta. 